НАУКИ О ЗЕМЛЕ

"НАУКА. ИННОВАЦИИ. ТЕХНОЛОГИИ", №4, 2019

25.00 .23

УДК 616.9-036.2(470.63)

ФИЗИЧЕСКАЯГЕОГРАФИЯ И БИОГЕОГРАФИЯ, ГЕОГРАФИЯ ПОЧВ

ИГЕОХИМИЯ ЛАНДШАФТОВ

Сигида С.И. Северо-Кавказский Федеральный университет, г. Ставрополь, Россия

\title{
ПРИРОДНЫЕ ОЧАГИ ТУЛЯРЕМИИ НА ТЕРРИТОРИИ СТАВРОПОЛЬСКОГО КРАЯ
}

Введение.

Материалы и методы исследований.

В последние годы на территории Ставропольского края складывается напряженная ситуация со многими природно-очаговыми инфекциями туляремией, клещевым энцефалитом, лептоспирозом и другими. Возбудители этих заболеваний человека обитают в местных биоценозах, однако, встречаются и заносные (лихорадка Западного Нила). Выявление природных очагов, мониторинг их эпизоотической активности и определение уровня риска заражения людей необходимо для принятия тех или иных просилактических мер защиты населения данного региона. Так как без проведения полноценной системы наблюдения за ситуацией в природе риски эпидемиологических катастроф будут нарастать с каждым годом [1].

Сбор материала осуществляпся в различных районах Центрального Предкавказья в 2014-2019 гг. За этот период нами отработано 7800 ловушко/суток, отловлено 571 экземпляр мышевидных грызунов. При отлове грызунов использовали общепринятые зоолого-паразитологические методы. Наблюдения за численностью мелких млекопитающих (MМ) - одна из основных составляющих эпизоотологического обследования, которое осуществляли на основе различных методов количественного учета ММ. При этом, основное внимание уделяется обследованию скирд, ометов, строений, расположенных в окружении природных биотопов, а также зарослей кустарников, балок и оврагов, участков рудеральной растительности, агроценозов с зерновыми культурами, лесополос, околоводных биотопов, колоний грызунов, заброшенных и временно используемых человеком строений, других мест повышенного риска заражения людей туляремией, лептоспирозом, ГЛПС (зон рекреации, мест заготовок Результаты исследований сельскохозяйственной продукции и т.п.)

и их обсуждение.

За 10 месяцев 2019 г. в Ставропольском крае случаев заболевания туляремией не зарегистрировано, за аналогичный период 2018 года зарегистрировано 2 случая. При исследовании бактериологическим методом 50 проб иксодовых клещей (583 особи), 172 пробы мелких млекопитающих (606 особей), 5 проб воды, 5 проб сена, культура возбудителя туляремии не выделена. За указанный период серологическим методом (РНГА) исследовано 158 проб от мелких млекопитающих (сухая капля крови от 158 особей), в результате в 28 пробах из 7 районов обнаружены антитела к возбудителю туляремии.

Выводы.

На основании эпидемиологических, эпизоотологических и лабораторных исследований можно сделать вывод о сохранении активности природного очага туляремии на территории Ставропольского края. В местах наибольшей концентрации грызунов возможны локальные эпизоотии, не исключена спорадическая заболеваемость людей.

Ключевые слова природный очаг, возбудитель туляремии, мелкие млекопитающие, эпизоотическое значение 


\section{Natural Foci of Tularemia in the Stavropol Region}

Introduction. In recent years, on the territory of the Stavropol region there is a tense situation with many natural focal infections-tularemia, tick-borne encephalitis, leptospirosis and others. The causative agents of these human diseases live in local biocenoses, however, there are also infectious (West Nile fever). Identification of natural foci, monitoring of their epizootic activity and determining the level of risk of infection of people are necessary for the adoption of certain preventive measures to protect the population of the region. As without a full system of monitoring the situation in nature,

Materials and methods the risks of epidemiological disasters will increase every year [1].

of research.

The collection of material was carried out in various regions of the Central Caucasus in 2014-2019 during this period we worked 7800 traps/day, caught 571 specimens of mouse-like rodents. In time of the catching rodents used conventional Zoological and parasitological methods. Observations of the number of small mammals (MM) one of the main components of epizootological survey, which was carried out on the basis of various methods of quantitative accounting MM. Meanwhile, the focus was on the examination skird some of ometov, structures, surrounded by natural habitats, and thickets of bushes, hills and ravines, plots of ruderale vegetation, agriculture crops, forests, aquatic biotopes, colonies of rodents, abandoned and temporarily used buildings, and other places of high risk of human infection with tularemia, leptospirosis, HFRS (recreation areas, places of agricultural products, etc.)

Results and Discussion. For 10 months of 2019 in the Stavropol region cases of tularemia are not registered, for the same period of 2018 registered 2 cases. In the study of bacteriological method 50 samples of Ixodes mites (583 individuals), 172 samples of small mammals ( 606 individuals), 5 samples of water, 5 samples of hay, the culture of the causative agent of tularemia was not isolated. During the specified period, 158 samples from small mammals (dry drop of blood from 158 individuals) were examined by serological method (RNGA), as a result, antibodies to the pathogen tularemia were found in 28 samples from 7 regions.

Conclusion. On the basis of epidemiological, epizootological and laboratory studies, it can be concluded that the activity of the natural focus of tularemia on the territory of Stavropol Krai is preserved. In places of the greatest concentration of rodents local epizootics are possible, sporadic morbidity of people is not excluded.

Key words: natural focus, the causative agent of tularemia, small mammal, epizootic significance.

Туляремия - природноочаговая инфекция, резервуаром которой являются многие виды мелких млекопитающих (представителей четырех основных семейств - мышевидных, заячьих, беличьих и тушканчиковых). На территории России основными носителями являются мышевидные грызуны - водяные крысы, ондатры, различные виды полевок [5].

У животных скрытное течение болезни, у человека наблюдается поражение легких, лимфатических узлов, кишечника. 
Заражение человека туляремией происходит от больных грызунов различными путями: контактным (через кожу, в том числе неповреждённую, или слизистую оболочку глаза) - при соприкосновении с больными или павшими зверьками, при снятии шкур с больных животных, разделке их туш, при контакте с объектами окружающей среды, загрязнёнными выделениями грызунов; трансмиссивным (через кожу) - при нападении кровососущих членистоногих (комаров, слепней, мошек, мокрецов, возможно иксодовых клещей); алиментарным - при употреблении воды или пишевых продуктов, загрязнённых выделениями грызунов; аспирационным - при вдыхании с воздухом пыли или капелек влаги, загрязнённых выделениями грызунов.

Туляремия природно-очаговая зоонозная инфекция. У человека - это острое инфекционное заболевание токсико-аллергического, септического характера. Возбудители туляремии является грамотрицательная коккобактерия Francisella tularensis из рода Francisella относящаяся к семейству Brucellacea.

На территории России выделено 7 основных ландшафтных типов природных очагов туляремии: пойменно-болотный, луго-полевой, степной, лесной, предгорно-ручьевой, тундровый и тугайный (пойменно-пустынный) со своими основными хозяевами возбудителя и эколого-эпидемиологическими особенностями. Человек очень чувствителен к туляремийному микробу, минимальная инфицирующая доза - одна микробная клетка. Животные по чувствительности к этому микроорганизму разделены на четыре группы. Н.Г. Олсуфьев выделяет две экологические формы возбудителя - «сухопутную», характеризующуюся передачей через иксодовых клещей (все три подвида), и «водную», связанную с околоводными видами грызунов и другими организмами - гидробионтами, с преимущественной передачей через воду и укусы комаров (голарктический подвид).

Переносчиками туляремийного микроба являются двукрылые насекомые семейства Culicidae следующих видов: Aedes vexans vexans Meig. 1830, A.cinereus Meigen 1818., Anopheles cloviger Meigen, 1804, Culex pipiens L.1758, C. Modestus Ficcalbi,1890, Ochlerotatus caspius Pallas, 1771, Oc. Flovescens Muller, 1764, Oc. punctor Kirby,1837. Перечисленные виды являются механическими переносчиками возбудителя туляремии, так как туляремийный микроб в организме переносчика не размножается и не развивается [3]. Природные очаги туляремии в России не имеют сплошного распространения [2].

Туляремия распространена и на территории Ставропольского края. Наши исследования позволяют констатировать наличие носителей - грызуны (полевка обыкновенная и общественная, мышь домовая) $[4,6,7]$.

Сложившаяся неблагополучная эпидемиологическая обстановка по туляремии на территории Ставропольского края дает основание на проведение мониторинга численности ММ с последующим лабораторным исследованием их на наличие возбудителя туляремии[8]. 


\section{Материал и методы}

Эпизоотологическое обследование по туляремии проводилось в 2014-2019 гг. проводилась в различных районах Ставропольского края.

Интенсивные исследования учеты численности грызунов проводились в Петровском районе, где в январе, марте и августе высталенно 1400 ловушко/ночей, в результате чего отловлено 72 особи ММ.

В указанное время нами проведено 7800 ловушко/ночей, отловлено 571 экз. ММ. Для выявления возбудителя туляремии биологическим методом отобрано 240 проб (селезенка), 15 проб воды, 15 проб сена, 300 пулов иксодовых клещей.

При отлове грызунов использовали общепринятые зоолого-паразитологические методы. Наблюдения за численностью мелких млекопитающих (MМ) - одна из основных составляющих эпизоотологического обследования, которое осуществляли на основе различных методов количественного учета ММ. При этом, основное внимание уделяется обследованию скирд, ометов, строений, расположенных в окружении природных биотопов, а также зарослей кустарников, балок и оврагов, участков рудеральной растительности, агроценозов с зерновыми культурами, лесополос, околоводных биотопов, колоний грызунов, заброшенных и временно используемых человеком строений, других мест повышенного риска заражения людей туляремией, лептоспирозом, ГЛПС (зон рекреации, мест заготовок сельскохозяйственной продукции и т.п.).

Для исследования на наличие антител к возбудителю туляремии и туляремийного антигена отобрано 240 проб сухой капли крови, 190 проб погадок хищных птиц и передано в лабораторию ООИ и ПЦР исследований.

- $\quad$ При исследовании методом РНАт погадок в 2014 году титры антигена $1: 10+++$ обнаружены в 1 пробе из Минераловодского района; в 2015 году титры антигена 1:20+++ и 1:10+1+ обнаружены в 2 пробах из Грачевского района (c. Спицевка); в 2016 году положительные результаты получены в 6 пробах из Минераловодского района (пос. Бородыновка): $1: 20+++$ - 3, 1:10+++ - 3, в 1 пробе из Шпаковского района (с. Сенгелеевское).

В 2014 г. при исследовании методом РНГА-РНАг проб от мелких млекопитающих, титры антител обнаружены у зверьков, отловленных в следующих районах края: Андроповском - 1:10+++ в 3 пробах от мыши лесной, 1:20+1+ от полевки обыкновенной, 1:40+++ от мыши лесной; Красногвардейском - 1:20+1+ от мыши домовой; Кочубеевском - 1:10++1 от полевки обыкновенной; Минераловодском - 
1:10+++ в 2 пробах от мыши лесной, 1:20+++ от мыши лесной, 1:20+++ от полевки общественной.

\begin{tabular}{|c|c|}
\hline- & $\begin{array}{l}\text { В } 2015 \text { г. при исследовании методом РНГА проб от мелких } \\
\text { млекопитающих, титры антител обнаружены у зверьков, } \\
\text { отловленных в следующих районах края: Красногвардейс- } \\
\text { ком - } 1: 10+++ \text { в } 2 \text { пробах от полевки обыкновенной; Пред- } \\
\text { горном - } 1: 20+++ \text { в } 4 \text { пробах от мыши лесной, } 1: 10+++ \text { в } 1 \\
\text { пробе от мыши лесной; Новоалександровском - } 1: 80+++ \text { в } \\
1 \text { пробе от мыши лесной, 1:20+++ в } 1 \text { пробе от бурозубки } \\
\text { обыкновенной. }\end{array}$ \\
\hline- & 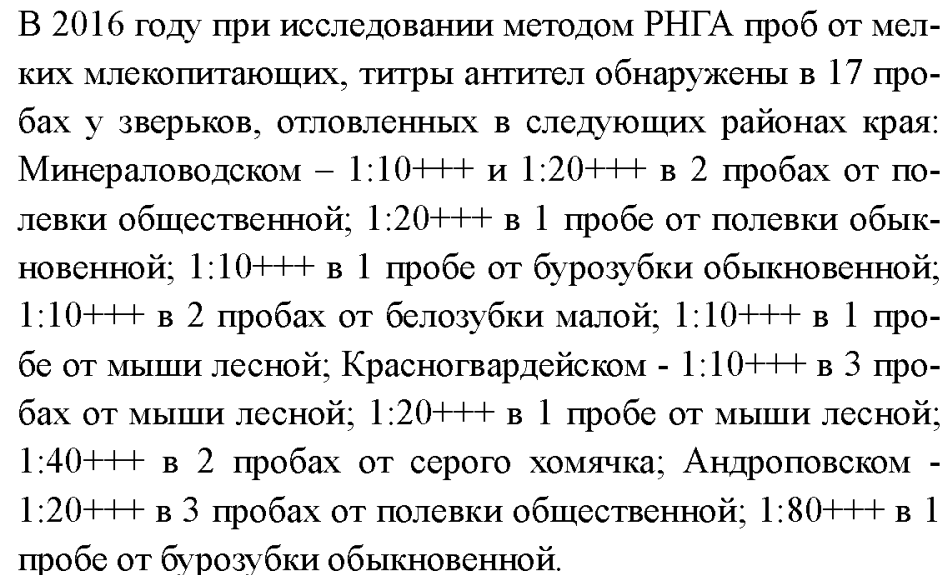 \\
\hline
\end{tabular}

На основании эпидемиологических, эпизоотологических и лабораторных исследований можно сделать вывод о сохранении активности природного очага туляремии на территории Ставропольского края. В местах наибольией концентрации грызунов возможны локальные эпизоотии, не исключена спорадическал заболеваемость людей.

\section{Эпизоотологическое обследование по туляремии терри-} тории Ипатовского района с 06.02.2017 по 09.02.2017 г.

Целью обследования проведение эпизоотологического обследования на туляремию в населенных пунктах: с. Красная Поляна, с. Золотаревка, с. Советское Руно, с. Тахта с последующим отбором полевого материала для лабораторного исследования на туляремию.

Во время эпизоотологического обследования на территории края установилась теплая $\left(+4{ }^{\circ} \mathrm{C}\right)$ с осадками погода, с резким похолоданием до минус $16-18{ }^{\circ} \mathrm{C}$ в последующие дни, сопровождающаяся сильным ветром и осадками в виде ледяного дождя переходящего в снег.

В результате затрачено 600 ловушко/ночей, отловлено 16 особей мелких млекопитающих, общий процент попадаемости по району составил $2,7 \%$. 
Доминирующим видом среди мелких млекопитающих, попавших в орудия лова, явилась полевка общественная - 15 особей, индекс доминирования составил $38,5 \%$, содоминантными видами явились: белозубка малая - 13 особей (ИД - 33,3\%).

В половом составе мелких млекопитающих соотношение самцов и самок составило 1:1. При вскрытии беременных самок не обнаружено.

\section{Стация №1}

При выборе стации в окрестностях с. Советское Руно выполнена глазомерно-балльная оценка местности, которая дала возможность получить представление о плотности заселения грызунов на данной территории (до 20 нор на $1 \mathrm{M}^{2}$ ). Выбрана лесокустарниковая стация вдоль поля с озимой пшеницей, затрачено 200 ловушко/ночей. Резкое похолодание и ледяной дождь в ночь с 6 на 7 февраля способствовали обледенению давилок «Геро», что могло снизить количество грызунов попавших в орудие лова. В результате отловлено пять полевок общественных.

Обследована лесозащитная полоса на протяжении 1 км, вблизи с. Советское Руно на наличие погадок хищных птиц, известно, что поедая в природе преимущественно ослабленных, больных зверьков или их трупы, хищники осуществляют выбор из популяции именно того материала, который желателен для лабораторного исследования, в результате собрано 8 погадок.

\section{Стация №2}

Отлов мышевидных грызунов осуществлялся на сельскохозяйственных полях вблизи с. Тахта, применена оценка местности по определению мышевидных грызунов на данной территории. Выбрана околоводная стация, ловушки выставлялись вдоль канала, заросшего камышом. Выставлено 100 ловушко/ночей, отловлено 3 особи полевки общественной, отметим, что погодные условия во время отлова сопровождались сильным ветром со снегом.

\section{Стация №3}

Отлов мышевидных грызунов осушествлялся на сельскохозяйственных полях вблизи с. Красная поляна, применена оценка местности по определению мышевидных грызунов на данной территории (до 20 нор на $1 \mathrm{м}^{2}$ ). Выбрана лесокустарниковая стация вдоль поля с озимой пшеницей, ловушки выставлялись вдоль поля с озимой пшеницей. Выставлено 100 ловушко/ночей, отловлена одна особь белозубки обыкновенной, погодные метеоусловия во время отлова сопровождались сильным ветром со снегом.

\section{Стация №4}

При выборе стации в окрестностях с. Золотаревка, выбрана околоводная стация, ловушки выставлялись вдоль канала, заросшего ка- 
мышом. Обследование стации показало большое количество нор грызунов. Затрачено 100 ловушко/ночей, в результате отловлено шесть полевок обшественных.

\section{Стация №5}

На территории с. Золотаревка выбрана закрытая стация (скирда) давилки выставили в количестве 100 ловушко/ночей, отловлена одна особь полевки общественной. В районе практически отсутствуют стации переживания грызунов (скирды).

При вскрытии грызунов, попавших в орудия лова у одной полевки общественной из с. Золотаревка увеличенна селезенка, с белыми пятнами.

В результате исследования 16 проб сухой капли крови, положительные результаты получены: из с. Советское Руно в четырех пробах от полевки общественной выделены титры антител к возбудителю туляремии: две 1:80+++ и две 1:10+++; из с. Красная Поляна от белозубки обыкновенной выделены титры антител к возбудителю туляремии 1:20+++; из с. Золотаревка в четыpex пробах от полевки общественной выделены титры антител: три пробы $1: 20+++$ и в одной пробе $1: 80+++$.

Результаты лабораторных исследований свидетельствует о прошедшей эпизоотии среди мелких млекопитающих.

При исследовании 21-й погадки хищных птиц титры антигена выделены 1:10++ в одной пробе собранной вблизи с. Советское Руно в лесозащитной полосе.

\section{Туляремия}

За 10 месяцев 2019 г. в крае случаев заболевания туляремией не зарегистрировано, за аналогичный период 2018 года зарегистрировано 2 случая.

При исследовании методом ПЦР 16 пулов иксодовых клещей (43 особи) генетический материал возбудителя обнаружен в 2 пулах, в т.ч.: 1 пул от Dermacentor reticulatus (Ипатовский район, пос. Винодельненский); 1 пул Dermacentor marginatus (Ипатовский район, с. Первомайское).

При исследовании бактериологическим методом 50 проб иксодовых клещей (583 особи), 172 пробы мелких млекопитающих (606 особей), 5 проб воды, 5 проб сена, культура возбудителя туляремии не выделена.

За 10 месяцев 2019 года серологическим методом (РНГА) исследовано 158 проб от мелких млекопитающих (сухая капля крови от 158 особей), в результате в 28 пробах из 7 районов обнаружены антитела к возбудителю туляремии, в т.ч.:

\section{Красногвардейский район:}

с. Красногвардейское, титры Ат 1:10+++ в 1 пробе от мыши малой лесной; 


\section{Предгорный район}

пос. Санамер, садовое товарищество «Здоровье», титры Ат 1:20+++ от 1 мыши малой лесной;

c. Этока, титры Ат 1:10+++ от 1 полевки обыкновенной; Благодарненский район

с. Красный Ключ, титры Ат 1:10+++ в 1 пробе от хомячка серого;

с. Сотниковское, титры Ат 1:10+++ в 1 пробе от хомячка серого;

с. Шишкико, титры Ат 1:10+++ в 1 пробе от мыши малой лесной;

Георгиевский район

с. Новозаведенное, титры Ат 1:20+++ в 1 пробе от мыши малой лесной, 1:20+++ в 1 пробе от мыши домовой;

г. Георгиевск, титры Ат 1:10+++ в 1 пробе от полевки общественной, 1:20+++ - в 1 пробе от мыши малой лесной;

Новоалександровский район

х. Фельдмаршальский, титры Ат 1:20++ в 2 пробах от полевок общественных;

с. Раздольное, титры Ат 1:10+++ в 1 пробе от полевки общественной; 1:10+++ в 1 пробе от мыши домовой;

пос. Курганный, титры Ат 1:10+++ в 1 пробе от белозубки малой;

Апанасенковский район

с. Воздвиженское, титры Ат 1:10+++ в 3 пробах от белозубок мальх;

с. Вознесеновское, титры Ат 1:10+++ в 1 пробе от мыши малой лесной;

с. Дивное, титры Ат 1:20+++ в 1 пробе от мыши малой лесной;

Ипатовский район

с. Кундули, титры Ат 1:10+++ в 2 пробах от мышей домовых, 1:20++1 - в 1 пробе от мыши малой лесной;

с. Бурукшун, титры Ат $1: 10+++$ в 2 пробах от полевок общественных, 1:10+++ и 1:20++ - в 2 пробах от мышей малых лесных; 1:20+++ - в 1 пробе от мыши домовой.

\section{Выводы:}

1. На основании эпидемиологических, эпизоотологических и лабораторных исследований можно сделать вывод о сохранении активности природного очага туляремии на территории Ставропольского края. В местах наибольшей концент- 
рации грызунов возможны локальные эпизоотии, не исключена спорадическая заболеваемость людей Возникновение заболеваний среди людей определяется эпизоотическим состоянием очагов. Разлитые эпизоотии туляремии происходят в годы высокой численности мелких млекопитающих, учитывая, высокую плотность колоний грызунов в лесозащитных насаждениях говорит о продолжающимся процессе размножения. Можно прогнозировать увеличение численности грызунов в лесозащитных насаждениях в весенний период, поэтому на данной территории не исключается локальная активность природных очагов туляремии

\section{Библиографический список}

1. Вержуцкий Д.Б. Современное состояние зоологической работы по обеспечению эпидемиологического благополучия России // Байкальский зоологический журнал. 2013.

2. Малышева Н.С., Гладких К.А. Кровососущие комары (Diptera: Culicidae) как возможное звено в трансмиссии возбудителей некоторых заболеваний человека на территории Курской области // Электронный научный журнал Курского государственного университета 2014.

3. Степин А.Ю. Кровососущие комары (Diptera: Culicidae) Оренбургской области // Усра. 2002. 83 с.

4. Попов П.Н. и др. Эпизоотическая активность природного очага туляремии в Ставропольском крае // Инфекционные болезни 2011. 44 c.

5. Кудрявцева Т.Ю. и др. Туляремия: актуальные вопросы и прогноз эпидемической ситуации на территории Российской Федерации в 2018 г. // Проблемы особо опасных инфекций. 2018, вып. 1.22 c

6. Левченко Б.И. и др. Роль отдельных видов мелких млекопитающих в поддержании природной очаговости на территории лесостепной части природного очага туляремии Ставропольского края // Проблемы особо опасных инфекций, вып. 3, 2014. 30 с.

7. Тихенко Н.И. и др. Эпизоотическое значение землероек белозубок в природном очаге туляремии степного типа в Ставропольском крае // Медицинская паразитология и паразитарные болезни 2001:2: 46-48 с.

8. Транквилевский Д.В. и др. Вопросы организации мониторинга природных очагов инфекций опасных для человека: планирование, проведение и анализ результатов полевых наблюдений // Эпидемиология №8 (257) 2015. 38 с. 


\section{References}

1. Verzhucky D.B. Current state of zoological work to ensure the epidemiological welfare of Russia // Baikal zoological journal. 2013.

2. Malysheva N.S., Gladkyh K.A. Blood-sucking mosquitos as a possible link in the transmission of pathogens of certain human diseases in the territory of the Kursk Region // Electronic scientific journal of Kursk university. 2014.

3. Stepin A.Y., Blood-sucking mosquitos (Diptera: Culicidae) Orenburg region // Ufa. 2002. $83 p$.

4. Popov P. N. and others. Epizootic activity of the natural focus of tularemia in the Stavropol territory / / Infectious diseases 2011. 44 p.

5. Kudryavtseva T. Y. and others. Tularemiya: the actual issues and prognosis of epidemic situation in the territory of the Russian Federation in 2018 // Problems of especially dangerous infections. 2018, edition 1. $22 \mathrm{p}$.

6. Levchenko B. I. and others. The Role of individual species of small mammals in maintaining natural foci on the territory of the foreststeppe part of the natural focus of tularemia of the Stavropol territory // Problems of particularly dangerous infections, edition 3, 2014. $30 \mathrm{p}$.

7. Tikhenko N.I. and others. Epizootic significance of shrews in the natural focus of tularemia steppe type in the Stavropol territory /I Medical Parasitology and parasitic diseases 2001:2: 46-48 p.

8. Trankvilevsky D. V. and others. Questions of the organization of monitoring of natural foci of infections dangerous for the person: planning, carrying out and the analysis of results of field observations // Epidemiology No. 8 (257) 2015. 38 p.

Поступило в редакцию 08.11.2019, принята к публикации 02.12.2019

\section{6 aвторах}

Сигида Сергей Иванович - доктор биологических наук, профессор кафедры общей биологии и биоразнообразия ФГАОУ ВО «Северо-Кавказский федеральный университет»; Scopus ID, Researcher ID Phone: (8652) 33-08-55.

E-mail omophron@yandex.ru.

\section{About the authors}

Sigida Sergey Ivanovich - Doctor of Biological Sciences, Professor of the Department of General biology and biodiversity, North-Caucasus Federal University . Researcher ID Phone: (8652) 33-08-55.

E-mail: omophron@yandex.ru. 